Article

\title{
Intermediate formation enabled regioselective access to amide in the Pd-catalyzed reductive aminocarbonylation of olefin with nitroarene
}

\author{
Li Yang, Lijun Shi, Chungu Xia *, Fuwei Li \# \\ State Key Laboratory for Oxo Synthesis and Selective Oxidation, Suzhou Research Institute of LICP, Lanzhou Institute of Chemical Physics (LICP), Chinese \\ Academy of Sciences, Lanzhou 730000, Gansu, China
}

\section{A R T I C L E I N F O}

\section{Article history:}

Received 22 October 2019

Accepted 1 December 2019

Published 5 July 2020

\section{Keywords:}

Nitroarenes

Amides

$N$-intermediate

Aminocarbonylation

Regioselectivity

\begin{abstract}
A B S T R A C T
An efficient route for the palladium-catalyzed reductive aminocarbonylation of olefins with nitroarenes was developed using carbon monoxide (CO) as both reductant and carbonyl source, which enables facile access to amides with excellent regioselectivity and broad substrate scope. It is found that the counter anions of the Pd catalyst precursors significantly affect the reaction chemoselectivity and amide regioselectivity. Branched amides were mainly obtained with $\mathrm{K}_{2} \mathrm{PdCl}_{4}$ as the metal catalyst, and phosphine ligands had no influence on the regioselectivity but affected the catalytic reactivity. However, phosphine ligands had significant effects on aminocarbonylation regioselectivity when $\mathrm{Pd}\left(\mathrm{CH}_{3} \mathrm{CN}\right)_{4}(\mathrm{OTf})_{2}$ was used; monodentate phosphines tended to form branched amides, and bidentate phosphines mainly formed linear amides. Trapping experiments, primary kinetic studies, and control reactions with all possible $\mathrm{N}$-species reduced from nitroarene indicated that the catalytic synthesis of branched and linear amides produced nitrene (further converted to enamide) and aniline, respectively, different from the previous ligand-controlled regioselective synthesis of amides via the aminocarbonylation of olefins with amines. Furthermore, the proposed synthesis route could be applied in the synthesis of gram-scale propanil under mild conditions.
\end{abstract}

(C) 2020, Dalian Institute of Chemical Physics, Chinese Academy of Sciences. Published by Elsevier B.V. All rights reserved.

\section{Introduction}

Nitroarenes are generally cheaper, more readily available, and more functionally compatible than anilines as nitrogen sources [1-4]. Therefore, using nitroarenes as starting molecules is advantageous for preparing nitrogen-containing functional molecules in proper cascade reactions [5-19]. Notably, nitroarenes can be reduced to several corresponding $N$-species under different conditions [5-9,19], which provide various synthesis routes from nitroarenes via in situ intermediate for-

\section{mation control.}

Amides constitute an important class of $\mathrm{N}$-containing carbonyl compounds. They are ubiquitous in natural products, functional materials, marketed drugs, and pesticides [20-23], and are attractive intermediates for diverse synthesis [24,25]. Different from the traditional preparation of amides via condensation between carboxylic derivatives and amines, the aminocarbonylations of olefins with amines have been developed as amide synthesis routes over the last two decades [22-34]. However, the reductive carbonylation of olefins with

\footnotetext{
* Corresponding author. E-mail: cgxia@licp.cas.cn

* Corresponding author. E-mail: fuweili@licp.cas.cn

This work was funded by the National Key R\&D Program of China (2018YFB1501600), the Natural Science Foundation of China (21773271, 21972151).

DOI: 10.1016/S1872-2067(20)63561-6 | http://www.sciencedirect.com/science/journal/18722067 | Chin. J. Catal., Vol. 41, No. 7, July 2020
} 
nitroarenes to produce amides has rarely been investigated, although it could be a promising alternative with readily available nitroarenes as the $\mathrm{N}$-resource and better step-economy.

In 2013, Beller and coworkers [35] reported a pioneering Pd-catalyzed aminocarbonylation of olefins with nitroarenes (Scheme 1(a)); in their study, the nitroarene was in situ reduced to aniline with external $\mathrm{H}_{2}$ as a reducing agent, and linear amide was obtained as the major product without regioselectivity control [35]. Recently, an interesting procedure of aminocarbonylation of styrene with nitroarene for the synthesis of $\alpha, \beta$-unsaturated amide, was successfully developed by Wu's group (Scheme 1(b)). In their study, organometallic Mo(CO)6 was used as a CO source [36]. Moreover, the reductive carbonylation of nitroarenes with other partners to produce amides has also rarely been reported. Driver et al. [37] demonstrated the Pd-catalyzed aminocarbonylation of nitroarenes with aryl C-H bond, but only substrates with a pyridine directing group lead to the production of amides. The Ni-catalyzed reductive aminocarbonylation of nitroarenes with aryl halides was developed; however, an excess solid reducing agent ( $\mathrm{Zn} / \mathrm{Mg}$ powder) was needed [38]. Furthermore, these two examples used expensive $\mathrm{Mo}(\mathrm{CO})_{6}$ as the $\mathrm{CO}$ source and showed a low atom economy. Therefore, it is highly interesting and desirable to develop new and green catalytic procedures for the reductive carbonylation of nitroarenes.

It is generally accepted that in the carbonylation (including aminocarbonylation) of olefin, the phosphine ligand plays a key role in deciding the regioselectivity. Owing to the diverse $\mathrm{N}$-species originating from the reduction of $\mathrm{NO}_{2}$ group with $\mathrm{CO}$ $[16,17]$, we expect that a new reductive aminocarbonylation of olefins with nitroarenes to control regioselectivity could be developed via the formation of different intermediates. In this paper, we propose a method for the Pd-catalyzed selective aminocarbonylation of olefins with nitroarenes using $\mathrm{CO}$ as both reductant and carbonyl source (Scheme 1(c)). Detailed investigations revealed that the catalytic synthesis of branched and linear amides produced nitrene (further converted to enamide) and aniline, respectively, due to the nature of the Pd salt catalysts and their counter anions. This is different from the ligand-controlled regioselectivity in the aminocarbonylation of olefins with amines. Moreover, this catalytic procedure shows good olefin and nitroarene substrate scope.

(a) Pd-catalyzed aminocarbonylation of olefins with nitroarenes (M. Beller)

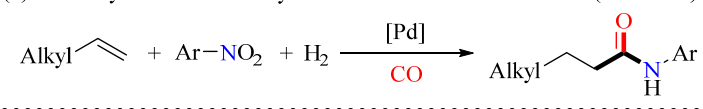

(b) Pd-catalyzed carbonylative synthesis of $a, b$-unsaturated amides $(\mathrm{X} . \mathrm{F} . \mathrm{Wu})$

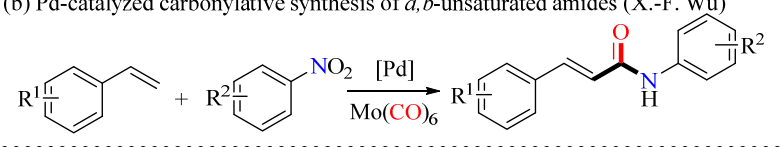

(c) Pd-catalyzed regioselective aminocarbonylation of olefin with nitroarene (this work)

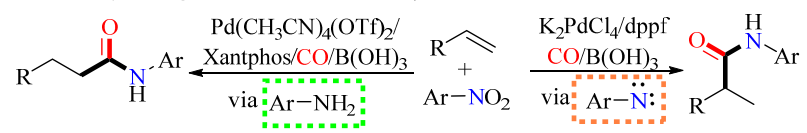

Scheme 1. Metal-catalyzed aminocarbonylation of olefin with nitroarene.

\section{Experimental}

\subsection{General methods}

NMR spectra were recorded at room temperature at 400 and $101 \mathrm{MHz}$ for ${ }^{1} \mathrm{H}$ and ${ }^{13} \mathrm{C}$, respectively, with $\mathrm{CDCl}_{3}$, DMSO-d or THF- $\mathrm{d}^{8}$ as the solvent. High resolution mass spectra (HRMS) were recorded with a Thermo Fisher Scientific LTQ FT Ultra in DART Positive Mode or an Agilent 6530 Accurate-Mass Q-TOF LC/MS in ESI mode. IR spectra were recorded with a Nicolet 6700 at room temperature. Melting points were recorded with a Barnstead Electrothermal IA9100. All non-aqueous reactions and manipulations were performed using standard Schlenk techniques. All solvents were purified using a Pure Solv 7-SDS solvent drying system. Unless otherwise stated, materials were obtained from commercial suppliers and used without further purification. All reactions were monitored via thin-layer chromatography (TLC) with $0.25 \mathrm{~mm}$ silica gel glass plates. A GC-MS analysis was performed with an Agilent 7890A/5975C GC-MS system.

\subsection{General procedure for the Pd-catalyzed reductive aminocarbonylation of olefin with nitroarene}

\subsubsection{General catalytic procedure for the synthesis of branched amides (3)}

Olefin (1, $0.2 \mathrm{mmol})$, nitroarene (2, $0.2 \mathrm{mmol}), \mathrm{K}_{2} \mathrm{PdCl}_{4}(3.3$ $\mathrm{mg}, 5 \mathrm{~mol} \%$ ), dppf (5.5 mg, $5 \mathrm{~mol} \%$ ), B(OH)3 (24.8 mg, 0.4 $\mathrm{mmol})$, and THF (2.5 mL) were sequentially added into an autoclave, which was then purged three times before charging with 3.5 MPa CO. The autoclave was put into the heating jacket. The solution was first stirred at $80^{\circ} \mathrm{C}$ for $20 \mathrm{~h}$ and then cooled to room temperature; $\mathrm{CO}$ was released carefully once the reaction finished. Then, the solvent was removed under reduced pressure, and the residue was purified by column chromatography on silica gel using pentane/ethyl acetate $(4: 1)$ as an eluent to obtain the desired branched product 3.

\subsubsection{General catalytic procedure for the synthesis of linear products (4)}

Olefin (1, $0.2 \mathrm{mmol})$, nitroarene (2, $0.2 \mathrm{mmol})$, $\mathrm{Pd}\left(\mathrm{CH}_{3} \mathrm{CN}\right)_{4}(\mathrm{OTf})_{2}(5.7 \mathrm{mg}, 5 \mathrm{~mol} \%)$, Xantphos $(5.8 \mathrm{mg}, 5$ $\mathrm{mol} \%), \mathrm{B}(\mathrm{OH})_{3}(24.8 \mathrm{mg}, 0.4 \mathrm{mmol})$, and THF (2.5 mL) were added into a glass tube, which was then placed in an autoclave. Then, the autoclave was purged three times and charged with $0.1 \mathrm{MPa}$ CO. The autoclave was put into the heating jacket, and the solution was stirred at $80{ }^{\circ} \mathrm{C}$ for $20 \mathrm{~h}$. Finally, branched amide 4 was obtained following the previous procedure.

\section{Results and discussion}

\subsection{Reaction conditions optimization}

Initially, the reductive aminocarbonylation of styrene (1a) with 3-chloro-nitrobenzene (2a) was taken as the model reaction. As shown in Table 1, there are two more hydrogens in the branched (3aa) and linear amide products (4aa) compared to 
their corresponding substrates. Therefore, hydrogen sources are one of the key factors in achieving the proposed reductive aminocarbonylation transformation. Accordingly, we first screened the influence of the hydrogen source using $\mathrm{K}_{2} \mathrm{PdCl}_{4} / \mathrm{dppf}$ as the catalytic system (Table 1). Interestingly, $\mathrm{H}_{2} \mathrm{O}$ gave an $82 \%$ yield of 3aa (entry 1); $p$-toluene sulfonic acid showed similar reactivity (entry 2), but other organic acids showed lower reactivity. Organic boric acid and acetic acid provided 3aa in 16\% (entry 3) and 5\% (entry 4) yields, respectively. As observed in Beller's work, nitroarene was catalytically reduced to aniline derivatives under $\mathrm{H}_{2}$ atmosphere [35], and a $68 \%$ yield of linear $4 \mathbf{a a}$ was obtained as the major amide product with simultaneous isolation of $17 \%$ yield of 3aa (entry 5). A yield of 3aa of only 5\% was obtained using the phosphoric acid as the hydrogen source (entry 6). $\mathrm{B}(\mathrm{OH})_{3}$ was found to be the best hydrogen source in this catalytic procedure, achieving a $98 \%$ yield of 3aa (entry 7 ).

Subsequently, with $\mathrm{B}(\mathrm{OH})_{3}$ as the hydrogen source, the influence of Pd precursors was investigated in the model reaction (Scheme 2). In general, the halogenated Pd precursors, regardless of their neutral or ionic nature, showed good selectivity to branched amide 3aa, and the ionic $\mathrm{K}_{2} \mathrm{PdCl}_{4}$ achieved a near quantitative yield of the 3aa; on the other hand, other non-halogenated Pd precursors with different counter anions displayed different regioselectivity and even chemoselectivity. The ionic $\mathrm{Pd}\left(\mathrm{CH}_{3} \mathrm{CN}\right)_{4} \mathrm{X}_{2}$ with a lower electron affinity anion, for example, $\mathrm{X}=\mathrm{BF}_{4}$ or OTf, provided linear 4aa as the major product with a yield of approximately $70 \%$. Other normally used neutral Pd salts containing non-halogen anions (such as $\mathrm{Pd}(\mathrm{acac})_{2}$ and $\mathrm{Pd}\left(\mathrm{NO}_{3}\right)_{2}$ ) revealed completely different chemoselectivity; only the reduction and reductive carbonylation of the 3-chloronitrobenzene were observed, yielding 3-chloroaniline (5a) and/or 1-chloro-3-isocyanato-benzene (6a) as the major products. These investigations indicate that $\mathrm{K}_{2} \mathrm{PdCl}_{4}$ and $\mathrm{Pd}\left(\mathrm{CH}_{3} \mathrm{CN}\right)_{4}(\mathrm{OTf})_{2}$ are excellent Pd precursors for the synthesis of branched and linear amides, respectively.

As previously mentioned, the ligand has been proved to be a crucial factor influencing the regioselectivity and activity of the olefin carbonylation [28-34,39-47]. In the model of aminocarbonylation under the optimal $\mathrm{K}_{2} \mathrm{PdCl}_{4} / \mathrm{B}(\mathrm{OH})_{3}$ catalytic system shown in Scheme 3 (left part), it was found, surprisingly, that

Table 1

Screen of hydrogen sources under the catalytic system of $\mathrm{K}_{2} \mathrm{PdCl}_{4} / \mathrm{dppf}$.

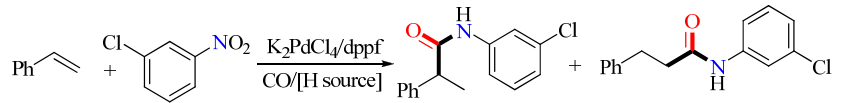

\begin{tabular}{lcc}
\multicolumn{1}{c}{ 1a } & \multicolumn{1}{c}{ 3aa } & 4aa \\
\hline Entry & Hydrogen sources (equiv.) & Yield \\
\hline 1 & $\mathrm{H}_{2} \mathrm{O}(2)$ & $82 \%$ 3aa \\
2 & $\mathrm{TsOH} \cdot \mathrm{H}_{2} \mathrm{O}(1)$ & $85 \%$ 3aa \\
3 & $\mathrm{PhB}(\mathrm{OH})_{2}(2)$ & $16 \%$ 3aa \\
4 & $\mathrm{AcOH}(2)$ & $5 \%$ 3aa \\
$5^{*}$ & $\mathrm{H}_{2}(1.0 \mathrm{MPa})$ & $17 \%$ 3aa + 68\% 4aa \\
6 & $\mathrm{H}_{3} \mathrm{PO}_{4}(2)$ & $5 \%$ 3aa \\
7 & $\mathrm{~B}(\mathrm{OH})_{3}(2)$ & $98 \%$ 3aa \\
\hline
\end{tabular}

Reaction conditions: Styrene (1a, $0.2 \mathrm{mmol}$ ), 3-chloronitrobenzene (2a, $0.2 \mathrm{mmol}), \mathrm{K}_{2} \mathrm{PdCl}_{4}(0.01 \mathrm{mmol}), \operatorname{dppf}(0.01 \mathrm{mmol})$, hydrogen source, THF (2.5 mL), CO (3.5 MPa); $80^{\circ} \mathrm{C}, 20 \mathrm{~h}$, isolated yield. * CO (2.5 MPa).
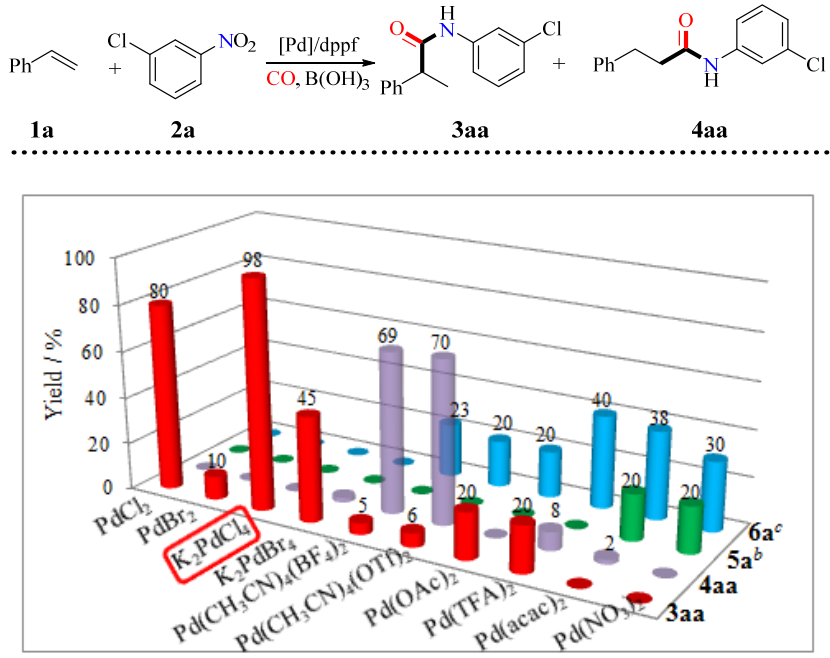

Scheme 2. Effect of Pd precursors in the reductive aminocarbonylation of olefin with nitroarene. ${ }^{a}{ }^{a}$ Reaction conditions: 1 a $(0.2 \mathrm{mmol}), 2 \mathrm{a}(0.2$ mmol), [Pd] (0.01 mmol), dppf (0.01 mmol), B(OH) 3 (0.4 mmol), THF $(2.5 \mathrm{~mL}), \mathrm{CO}(3.5 \mathrm{MPa}) ; 80^{\circ} \mathrm{C}, 20 \mathrm{~h}$, isolated yield. $b \mathbf{5 a}$ is 3 -chloroaniline. ${ }^{c} \mathbf{6} \mathbf{a}$ is 1-chloro-3-isocyanato-benzene.

the phosphine ligands could not affect the aminocarbonylation regioselectivity but significantly influenced the catalytic activity; dppf gave $98 \%$ yield and $100 \%$ selectivity of 3aa. On the contrary, these phosphine ligands had a significant influence on the regioselectivity in the corresponding aminocarbonylation of olefin with amine compound as the $\mathrm{N}$-source; the dppf ligand yielded linear amide as the major product, and $\mathrm{PPh}_{3}$ had the best 3aa yield (right part of Scheme 3). These control results primarily indicate that the present aminocarbonylation of olefin with nitroarene as $\mathrm{N}$-source under the $\mathrm{K}_{2} \mathrm{PdCl}_{4} / \mathrm{B}(\mathrm{OH})_{3}$ catalytic system does not produce the reduced amine intermediate, and its regioselectivity control is different from that of the traditional aminocarbonylation with amine as $\mathrm{N}$-source.

Ionic $\mathrm{Pd}\left(\mathrm{CH}_{3} \mathrm{CN}\right)_{4}(\mathrm{OTf})_{2}$ with an electrophilic -OTf anion mainly provided linear products (4aa) (Scheme 2), and $\mathrm{B}(\mathrm{OH})_{3}$ was found to be the optimal hydrogen source for the synthesis of linear 4aa (Table S1). With $\mathrm{Pd}\left(\mathrm{CH}_{3} \mathrm{CN}\right)_{4}(\mathrm{OTf})_{2} / \mathrm{B}(\mathrm{OH})_{3}$ as the catalyst system, the ligand effect on the synthesis of linear products was investigated, as illustrated in Scheme 4. The ligand showed a different regioselectivity control with $\mathrm{K}_{2} \mathrm{PdCl}_{4}$ as the metal precursor. Bidentate phosphines with rigid skeletons yielded linear amide as the major product; Xantphos was the optimal ligand, achieving a $92 \%$ amide yield and an $80 \%$ regioselectivity to 4aa, while monodentate phosphine ligands tended to form branched amides with low yields. Thus, $\mathrm{Pd}\left(\mathrm{CH}_{3} \mathrm{CN}\right)_{4}(\mathrm{OTf})_{2} / \mathrm{Xantphos} / \mathrm{B}(\mathrm{OH})_{3}$ was selected as the catalyst system for the reductive aminocarbonylation of olefin to linear amide.

Other reaction conditions, including CO pressure, solvent, temperature, and reaction time, were also systematically tested. With $\mathrm{K}_{2} \mathrm{PdCl}_{4} / \mathrm{dppf} / \mathrm{B}(\mathrm{OH})_{3}$ as the catalytic system, the amide yields decreased sharply when lowering the CO pressure (Table S2), but no regioselectivity effects were observed. The pressure for the synthesis of branched amide (Table S2, entry 1) was set to $3.5 \mathrm{MPa}$. In the preparation of linear amide under 


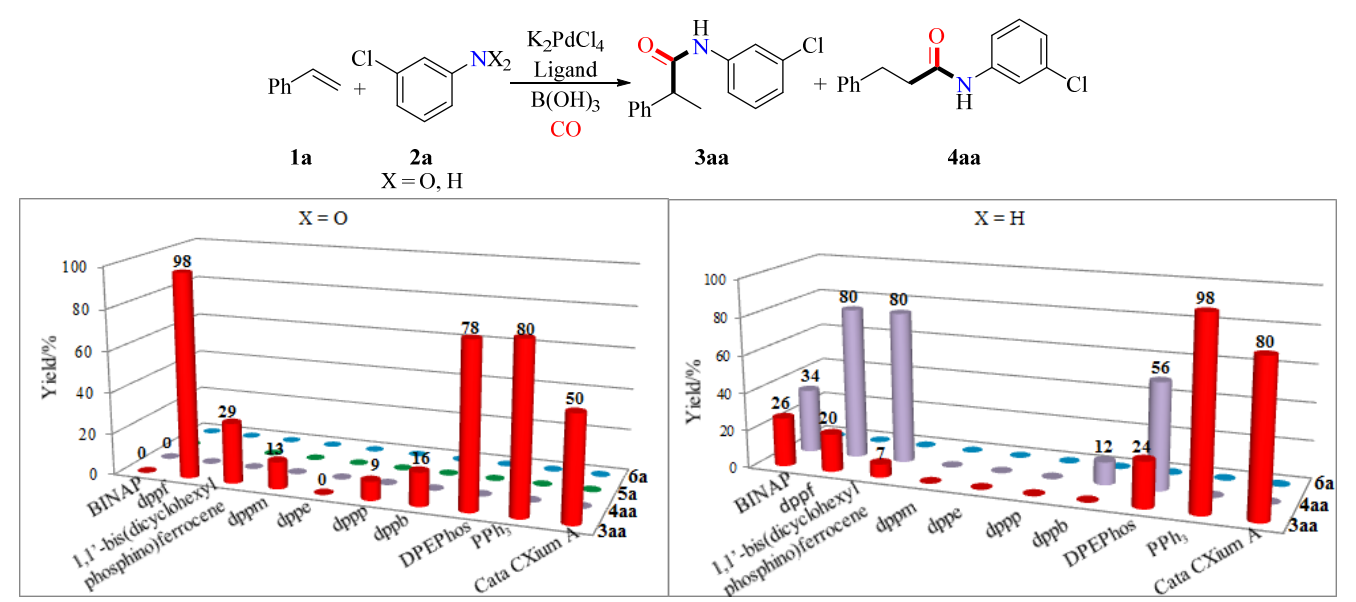

Scheme 3. Ligand effect in the reductive aminocarbonylation of olefin with nitroarene and aniline. Reaction conditions: $1 \mathrm{a}(0.2 \mathrm{mmol}), \mathbf{2 a}(0.2 \mathrm{mmol})$ $\mathrm{K}_{2} \mathrm{PdCl}_{4}(0.01 \mathrm{mmol})$, ligands $(0.01$ or $0.02 \mathrm{mmol}), \mathrm{B}(\mathrm{OH})_{3}(0.4 \mathrm{mmol})$, THF $(2.5 \mathrm{~mL}), \mathrm{CO}(3.5 \mathrm{MPa}) ; 80^{\circ} \mathrm{C}, 20 \mathrm{~h}$, isolated yield.

the $\mathrm{Pd}\left(\mathrm{CH}_{3} \mathrm{CN}\right)_{4}(\mathrm{OTf})_{2} /$ Xantphos/B(OH) $)_{3}$ catalytic system, the CO pressure had little effect on the reactivity, and a lower pressure led to a higher selectivity (Table S2). A 79\% yield of 4aa could be obtained at a CO pressure as low as $0.1 \mathrm{MPa}$ (Table S2, entry 5). As presented in Table S3, the solvent polarity significantly affected both the catalytic activity and selectivity in the synthesis of branched and linear amides. Highly polar solvents were advantageous for the hydrogenation of nitroarene; only a small amount of carbonylated product was isolated (Table S3, entries 7-9). The moderately polar THF was the common solvent for the synthesis of these two amides (Table S3, entry 3). The product yield decreased sharply at relatively low temperature without change in regioselectivity (Table S4), and the optimal yields of linear and branched amides were obtained at $80^{\circ} \mathrm{C}$. Finally, the kinetic profile of the reductive aminocarbonylations of styrene (1a) and 3-chloronitrobenzene (2a) were conducted under Condition A (Fig. S1) and Condition B (Fig. S2), respectively. The results showed that $20 \mathrm{~h}$ was the optimal reaction time for the two transformations, and compound 3-chloroaniline (5a) was generated at the beginning under Condition $\mathrm{B}$ and then gradually
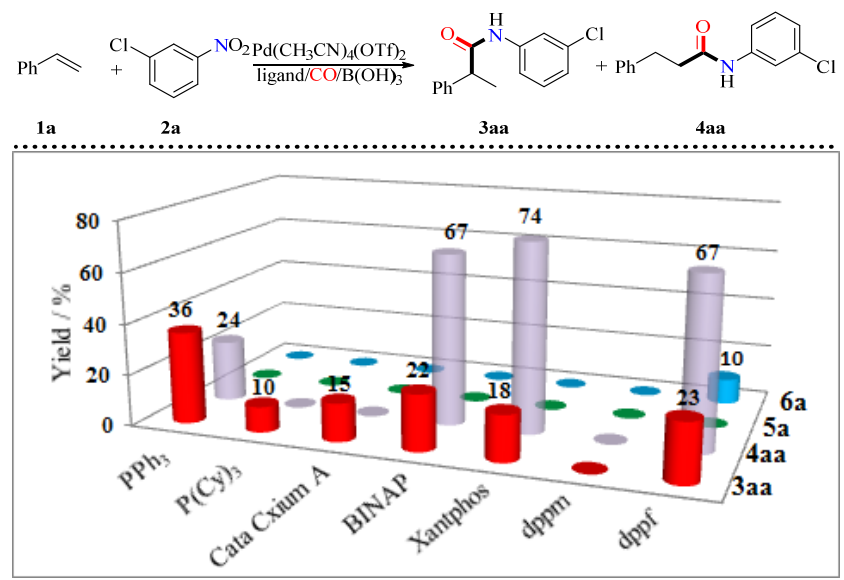

Scheme 4. Ligand effect in the reductive aminocarbonylation of olefin to linear products. Reaction conditions: 1 a $(0.2 \mathrm{mmol}), 2 \mathrm{a}(0.2 \mathrm{mmol})$, $\mathrm{Pd}\left(\mathrm{CH}_{3} \mathrm{CN}\right)_{4}(\mathrm{OTf})_{2}(0.01 \mathrm{mmol})$, ligands $(0.01$ or $0.02 \mathrm{mmol}), \mathrm{B}(\mathrm{OH})_{3}$ (0.4 mmol), THF (2.5 mL), CO (0.1 MPa); $80^{\circ} \mathrm{C}, 20 \mathrm{~h}$, isolated yield. increased to $\sim 47 \%$ before starting to decrease after $5 \mathrm{~h}$, implying that 3-chloroaniline (5a) may be one intermediate of the production of linear amide. In conclusion, the optimized condition for the synthesis of 3 aa was condition A: $5 \mathrm{~mol}^{\circ} \mathrm{K}_{2} \mathrm{PdCl}_{4}$, 5 mol\% dppf, 2 equiv. $\mathrm{B}(\mathrm{OH})_{3}, 2.5 \mathrm{~mL} \mathrm{THF}, 3.5 \mathrm{MPa} \mathrm{CO}, 80^{\circ} \mathrm{C}$, $20 \mathrm{~h}$, and condition B: $5 \mathrm{~mol} \% \mathrm{Pd}\left(\mathrm{CH}_{3} \mathrm{CN}\right)_{4}(\mathrm{OTf})_{2}, 5 \mathrm{~mol} \%$ Xantphos, 2 equiv. $\mathrm{B}(\mathrm{OH})_{3}, 2.5 \mathrm{~mL} \mathrm{THF}, 0.1 \mathrm{MPa} \mathrm{CO}, 80^{\circ} \mathrm{C}, 20 \mathrm{~h}$, were for the formation of $\mathbf{4 a a}$.

\subsection{Substrate scope}

For the preparation of the branched amides under condition A, the scope and limitations of this catalytic system toward various olefins were first investigated, and the results are depicted in Scheme 5. Styrenes with a series of functional groups

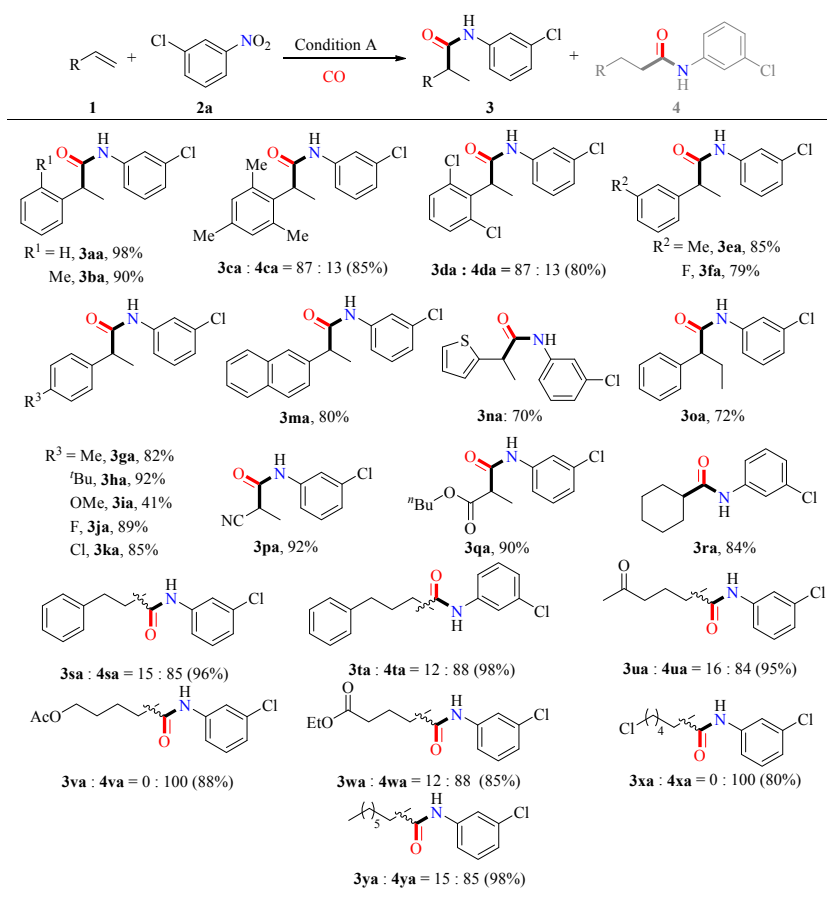

Scheme 5. Olefin scope in the synthesis of branched amides under Condition A. 
on the ortho-, meta-, and para-positions were compatible with the optimal condition to afford the corresponding branched products (3aa-3ka) in good to excellent yields and high regioselectivities. Specifically, both electron-rich and electron-deficient ortho-disubstituted styrenes could also produce branched products with good yields and high regioselectivity (3ca and 3da). Interestingly, an increasing steric hindrance of the vinyl group had little effect on the formation of branched products with $100 \%$ selectivity (3oa), and, notably, no isomerized olefin (allylbenzene) or its aminocarbonylation product was obtained. Sulfur-containing heterocyclic olefin could also give a $70 \%$ yield of branched amide with $100 \%$ selectivity (3na). Furthermore, excellent yields of 3pa and 3qa were obtained in the reaction of aliphatic alkenes with functional groups. Representative cyclic alkene demonstrated high activity, achieving good yield of 3ra. Unexpectedly, when normal aliphatic olefins (1s-1y) were used, the main products under Condition A were linear amides, which followed the anti-Markovnikov rules $[48,49]$.

Subsequently, we investigated the scope of olefins under Condition B, as shown in Scheme 6. The ortho-steric hindrance of aromatic olefins could increase the regioselectivity for the synthesis of linear amides under Condition B (4ba, 4ca, and 4da). Good yields of linear products could be achieved by altering the reaction temperature and the $\mathrm{CO}$ pressure. Various functional groups, such as halogens, alkyl, and methoxy, contained in phenyl rings, were well tolerated under Condition B. The corresponding linear products were achieved with good to excellent yields and high selectivity. For the more challenging aliphatic olefins, good to excellent results were also obtained; moreover, aliphatic olefins with various substituents, such as

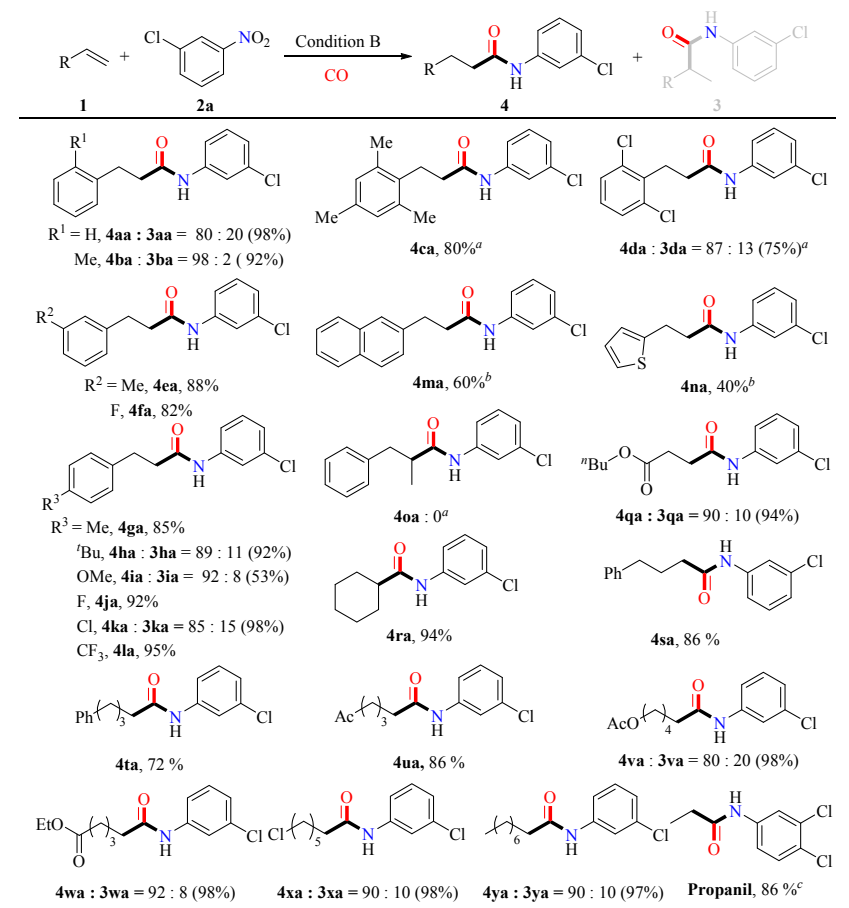

Scheme 6. Olefin scope in the synthesis of linear amides under Condition B. ${ }^{a} \mathrm{CO}(3.5 \mathrm{MPa}) ; 100{ }^{\circ} \mathrm{C} .{ }^{b} \mathrm{CO}$ (3.5 MPa). ${ }^{c} \mathbf{1}(1.5 \mathrm{MPa}), 2(10 \mathrm{mmol})$, $\mathrm{Pd}\left(\mathrm{CH}_{3} \mathrm{CN}\right)_{4}(\mathrm{OTf})_{2}(0.025 \mathrm{mmol})$, Xantphos $(0.025 \mathrm{mmol}), \mathrm{B}(\mathrm{OH})_{3}(20$ mmol), THF (25 mL), CO (0.1 MPa); $80^{\circ} \mathrm{C}, 20 \mathrm{~h}$. ketone, esters, and halogens, were compatible with the catalytic system under Condition B (4qa, 4ua, 4va, and 4xa). Notably, this transformation could be applied in the gram-scale synthesis of propanil (propanil is an acetanilide post-emergence herbicide with no residual effect, and is used against numerous grasses and broad-leaved weeds [50]), achieving excellent yield (86\%) with a much lower amount of catalyst (0.25 mol\%) and lower CO pressure (0.1 MPa).

Next, we turned our attention to study the scopes of nitroarenes using styrene (1a) as a standard coupling partner (Scheme 7). In previous reports, the aminocarbonylation was sensitive to the steric hindrance and electronic effects of the substituents on the anilines [35], but there were no obvious effects on the aminocarbonylation when using nitroarenes as nitrogen sources under Condition A. For example, the electron-rich or electron-deficient ortho-substituted derivatives gave good yields with $100 \%$ branched regioselectivity (3ad-3af). The steric hindrance of nitroarenes slightly reduced the activity under Condition B with excellent selectivity for the linear products (4ad-4af). The nitroarenes with nitrile (3ag), ester (3ah), and ketone (3ai) moieties worked efficiently under Condition A. Notably, with this procedure, which is perfectly suitable for the substrates with an aldehyde substituent, providing corresponding branched amide (3aj) with $90 \%$ yield and pure branched regioselectivity, it was usually necessary to protect the aldehyde group when the amine was used as a nitrogen source in the aminocarbonylation, particularly under the acid conditions. Other typical functional groups on the nitroarenes, such as halogen, ether, and alkyl, were also well tolerated under Condition A, producing the corresponding branched products in $88 \%-95 \%$ yields with $100 \%$ branched regioselectivity (3ak-3am). Aminocarbonylation with nitro-

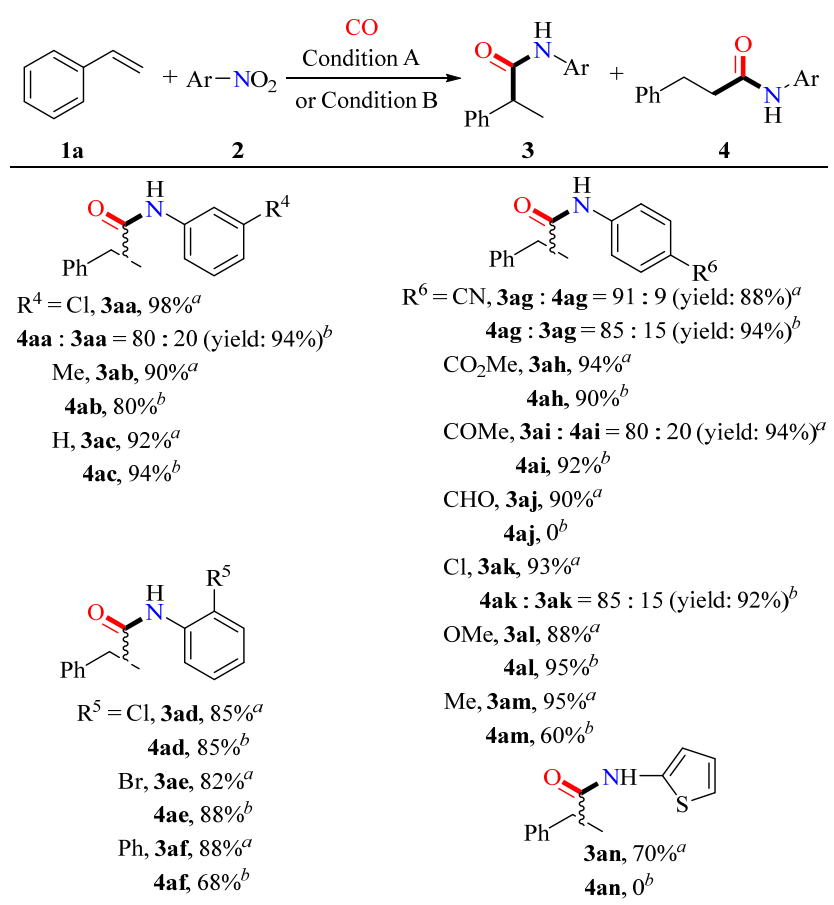

Scheme 7. Nitroarene scope in the synthesis of branched and linear amides under Condition $\mathrm{A}^{a}$ and Condition $\mathrm{B}^{b}$. 
thiophene also proceeded smoothly with a $70 \%$ yield of the desired 3an and 100\% regioselectivity (3an). Under Condition $\mathrm{B}$, the universality of nitro compounds was not as good as under Condition A. Electron-donating groups on the nitro compound slightly lowered the amide yields (4ab, 4af and 4am), and the nitrobenzene with a 4-aldehyde moiety (4aj) and nitrothiophene did not work under Condition B.

\subsection{Mechanistic insights}

The above differences in regioselectivity, reaction parameter effect, and substrate scope seem to indicate that the present selective carbonylations undergo different reaction pathways under Condition A and Condition B. It has been found that nitroarene can be catalytically reduced to nitrosoarene, aromatic amine, $\mathrm{N}$-aryl hydroxylamine, and aryl isocyanate under CO atmosphere [16,17,51-53]. Therefore, control reactions with these $\mathrm{N}$-species would provide more insights into the present aminocarbonylation with nitroarene as $N$-source. As illustrated in Scheme 8, when replacing nitroarene with its first reduced intermediate (nitrosoarene) under Condition A, the branched amide was obtained with a yield as small as $27 \%$ (Scheme $8(a)$ ii) while linear amide was obtained with a $68 \%$ yield. The yield of branched products could be significantly enhanced to $87 \%$ by dropwise addition of nitrosoarene over $15 \mathrm{~h}$ (Scheme 8(a)iii). This yield is close to that obtained under Condition A (Scheme 8(a)i), wherein the nitrosoarene was supposed to slowly release from the catalytic reduction of nitroarene, indicating that, under Condition A, the conversion of nitrosoarene to aniline was faster than its reductive aminocarbonylation. In the meantime, similar catalytic results were obtained in the aminocarbonylation of nitrosoarene and nitroarene under Condition B (Scheme 8(b)i and 8(b)ii)). In light of the results of this and previous works, it is proposed that nitrosoarene is the common $\mathrm{N}$-intermediate for the synthesis of branched and linear amides. Under Condition A, similar product distributions

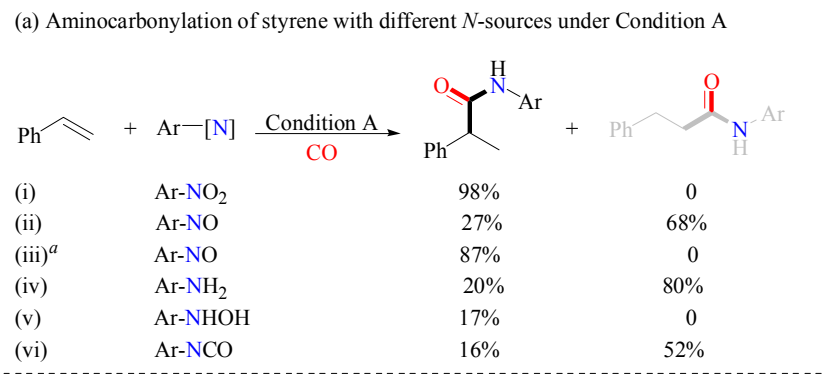

(b) Aminocarbonylation of styrene with different $N$-sources under Condition B

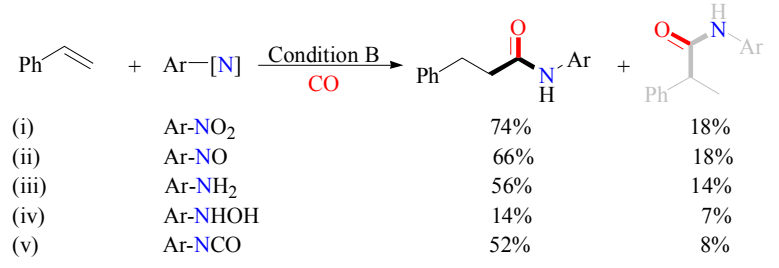

Scheme 8. Studies on the possible $N$-intermediates involved in the reductive aminocarbonylation. Ar $=3$ - chlorophenyl. ${ }^{a}$ Reaction in 5 mmol; 1-chloro-3-nitrosobenzene was added dropwise over $15 \mathrm{~h}$. were realized using aromatic amine and isocyanate as $\mathrm{N}$-source, unlike in the aminocarbonylation of nitroarene (Scheme 8(a)iv and 8(a)vi), but similar results were obtained using these three $N$-precursors under Condition B (Scheme 8(b)i, 8(b)iii, and 8(b)v). Thus, it is deduced that the production of linear amide possibly involves aromatic amine and/or aryl isocyanate, which, however, are not the intermediates in the synthesis of branched amide. This could be further verified from the previous result where $\mathrm{H}_{2}$ was used as a hydrogen source (Table 1, entry 4). Furthermore, the generation of 3-chloroaniline (5a) and its further carbonylation to linear $4 \mathbf{a a}$ were observed in the kinetic profile of the model reaction under Condition B (Fig. S2), indicating that the amine may be the intermediate for the production of the linear product. Very low yields of amides were isolated when $N$-aryl hydroxylamine was used under Condition A and Condition B (Scheme 8(a)v and 8(b)iv), possibly suggesting that $N$-aryl hydroxylamine was not the intermediate in the present carbonylations.

In the reductions of nitroarenes under $\mathrm{CO}$ atmosphere, palladium imido species " $\mathrm{Pd}=\mathrm{NPh}$ " was usually postulated as the key intermediate $[54,55]$. To seek the evidence for the existence of "Pd=NPh," attempts were made to trap this species by adding cyclohexene dropwise during a catalytic experiment under Condition A (Fig. 1) and Condition B (Scheme S1) $[17,56]$. As indicated by the mass and fragmentation pattern of the peak in the GC-MS spectrum (Fig. 1), the corresponding aziridine (7-(3-chlorophenyl)-7-azabicyclo[4.1.0]heptane) was indeed observed under Condition A. However, this trapping was not detected under Condition B (Scheme S1). Therefore, it is believed that the palladium imido species was the key intermediate for the formation of branched amides. It has been reported that azobenzenes could react with lower-valent metals to obtain the corresponding metal imido species $[7,9,57,58]$. To further support this hypothesis,

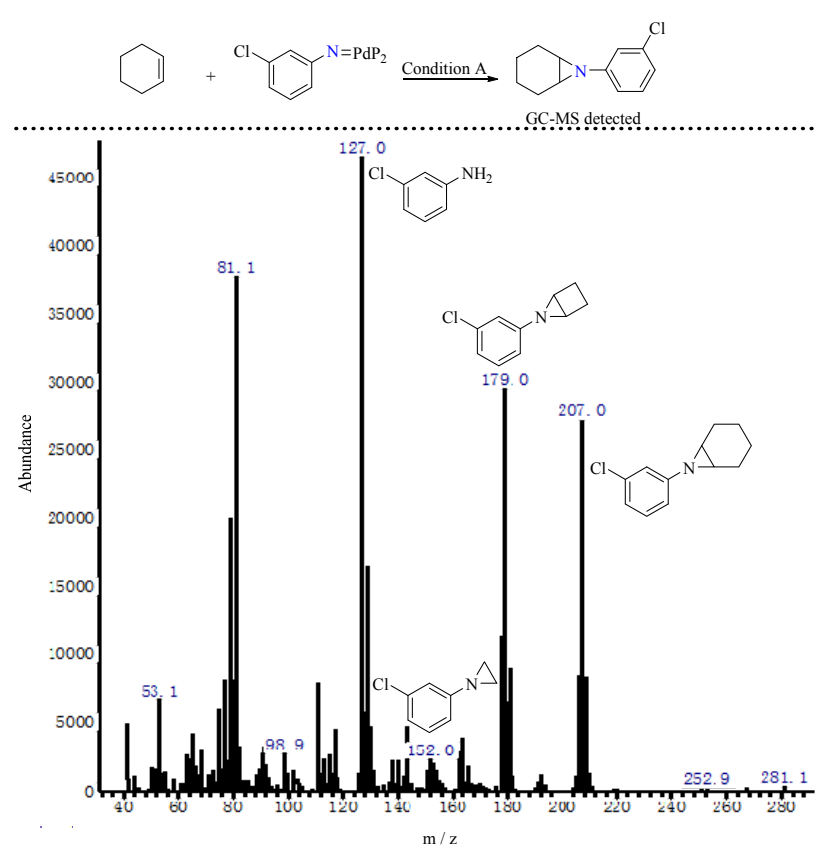

Fig. 1. The trapping experiment of an imido complex with cyclohexene. 
1,2-bis(3-chlorophenyl)diazene was used as the substrate to conduct the control experiments. A 62\% yield of branched 3aa was isolated under Condition $\mathrm{A}$, and no reaction occurred under Condition B (Scheme S2). These results show that different $\mathrm{N}$-intermediates were involved in the production of branched and linear products. Nitrene and its coordinated palladium imido species are the possible intermediates for the regioselective synthesis of branched amide.

In the ligand optimization for the preparation of branched products, $N$-(3-chlorophenyl)-2-phenylacrylamide (7aa) was detected by GC-MS when tris(4-methoxyphenyl) phosphine and DPEPhos were used as ligands. To probe whether $\mathbf{7 a a}$ was an intermediate or a byproduct, the reaction rate was reduced by lowering the $\mathrm{CO}$ pressure, as indicated in the model reaction (Fig. 2), Formation of 7aa was observed at the beginning; it gradually increased to $12 \%$ and kept this concentration before starting to decrease after $20 \mathrm{~h}$, implying that 7aa was one possible intermediate for the production of branched amide. Subsequently, 7aa was used as the substrate under Condition A, and 3aa was produced with a 92\% yield (Scheme 9). These results suggest that enamide was an intermediate for the synthesis of branched amide.

Based on our investigations and previous works $[5-15,37,38]$, the following catalytic cycles for the synthesis of branched and linear products were proposed, as shown in Scheme 10. The reductive aminocarbonylation was initiated by the reduction of nitroarene with $\mathrm{CO}$ via Pd-nitrosoarene (II) complex under both condition A and condition B [17,38]. Complete deoxygenation of the Pd-nitrosoarene (II) complex yielded nitrene intermediate (III) with $\mathrm{CO}_{2}$ releasing under Condition A $[17,38]$, which was verified by the situ-trapping experiment (Fig. 1). Subsequently, the addition of olefins to nitrene intermediate (III) and the insertion of $\mathrm{CO}$ occurred, followed by the reductive elimination to yield an enamide, which was reductively catalyzed by the eliminated $\operatorname{Pd}(0)$ and $\mathrm{CO}$ with the
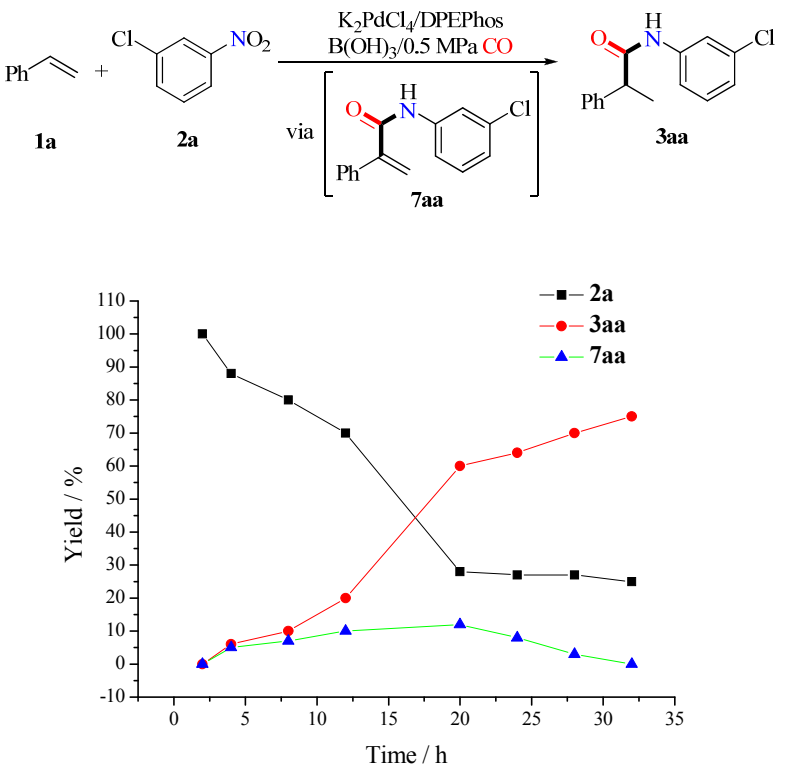

Fig. 2. Reaction profile for the synthesis of 3aa.

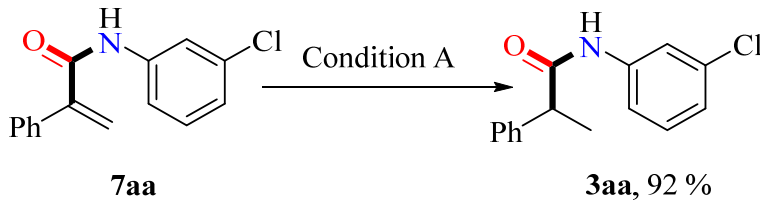

Scheme 9. Control experiment to further verify the production of 7aa intermediate.

help of $\mathrm{B}(\mathrm{OH})_{3}$ to provide the branched product 3 . This step could be reasonably deduced by the reaction profile (Fig. 2) and the controlled experiment (Scheme 9).

For the synthesis of linear products, the hydrodeoxygenation of the Pd-nitrosoarene (II) complex yielded the aromatic amine intermediate (5) [16,17], which was verified by the reaction profile for the synthesis of linear products (Fig. S2) and the controlled experiment (Scheme 8(b)iii). Subsequently, it followed a similar route in the reported aminocarbonylation of olefin with amine to produce linear amide (4) [30].

\section{Conclusions}

In summary, we have developed a route for the Pd-catalyzed selective aminocarbonylation of olefins with nitroarenes via different intermediates. Both the chemoselectivity (3-chloroaniline/1-chloro-3-isocyanato-benzene or amide) and the carbonylative regioselectivity are sensitive to the nature of counter anions of Pd(II) precursors. The nitroarene was completely deoxidized to nitrene and regioselectively carbonylated with olefin to yield branched amide using $\mathrm{K}_{2} \mathrm{PdCl}_{4}$ as the $\mathrm{Pd}$ precatalyst. The phosphine ligand hardly affected the carbonylation regioselectivity but affected the reactivity. On the other hand, the kinetic profile and controlled experiments revealed that nitroarene is first hydrogenated to aromatic amine, which is the essential intermediate for the production of linear products under the optimal $\mathrm{Pd}\left(\mathrm{CH}_{3} \mathrm{CN}\right)_{4}(\mathrm{OTf})_{2} /$ Xantphos/B $(\mathrm{OH})_{3}$ catalytic system. These catalytic systems provide facile and selective access to linear and branched amides and will aid the development of diverse synthetic routes through the formation of different $\mathrm{N}$-intermediates.

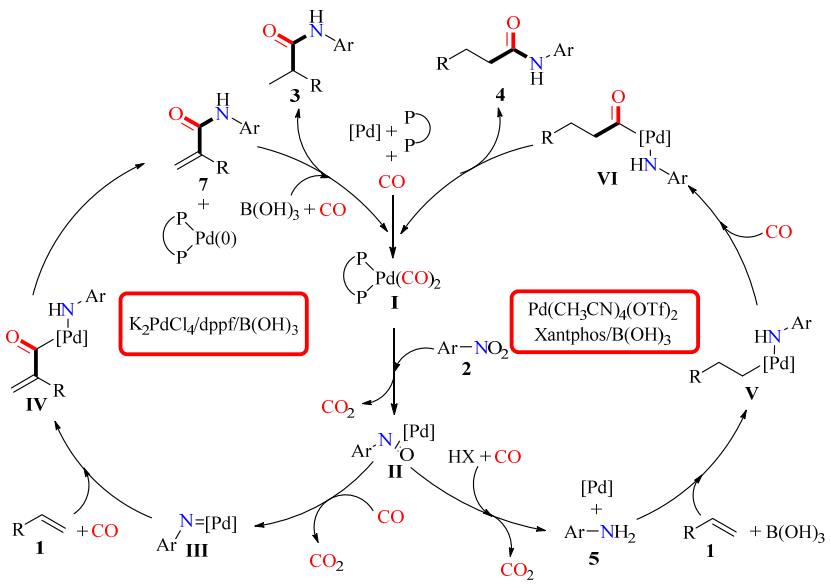

Scheme 10. Proposed reaction pathways for the selective aminocarbonylation. 


\section{References}

[1] J. S. Zhu, C. J. Li, K. Y. Tsui, N. Kraemer, J.-H. Son, M. J. Haddadin, D. J. Tantillo, M. J. Kurth, J. Am. Chem. Soc., 2019, 141, 6247-6253.

[2] M. Rauser, R. Eckert, M. Gerbershagen, M. Niggemann, Angew. Chem. Int. Ed., 2019, 58, 6713-6717.

[3] J. H. Gui, C. M. Pan, Y. Jin, T. Qin, J. C. Lo, B. J. Lee, S. H. Spergel, M. E. Mertzman, W. J. Pitts, T. E. L. Cruz, M. A. Schmidt, N. Darvatkar, S. R. Natarajan, P. S. Baran, Science, 2015, 348, 886-891.

[4] N. Ono, The Nitro Group in Organic Synthesis, Wiley-VCH, Weinheim, 2001, 1-2.

[5] C. W. Cheung, J. A. Ma, X. L. Hu, J. Am. Chem. Soc., 2018, 140, 6789-6792.

[6] T. V. Nykaza, A. Ramirez, T. S. Harrison, M. R. Luzung, A. T. Radosevich, J. Am. Chem. Soc., 2018, 140, 3103-3113.

[7] C. W. Cheung, M. L. Ploeger, X. L. Hu, Nat. Commun., 2017, 8, 14878-14887.

[8] M. Shevlin, X. Y. Guan, T. G. Driver, ACS Catal., 2017, 7, 5518-5522.

[9] C. W. Cheung, M. L. Ploeger, X. L. Hu, ACS Catal., 2017, 7, 7092-7096.

[10] R. Rubio-Presa, M. R. Pedrosa, M. A. Fernandez-Rodríguez, F. J. Arnaiz, R. Sanz, Org. Lett., 2017, 19, 5470-5473.

[11] Z. C. Lin, Z. Y. Hu, X. Zhang, J. H. Dong, J. B. Liu, D. Z. Chen, X. X. Xu, Org. Lett., 2017, 19, 5284-5287.

[12] M. Rauser, C. Ascheberg, M. Niggemann, Angew. Chem. Int. Ed., 2017, 56, 11570-11574.

[13] C. W. Cheung, X. L. Hu, Nat. Commun., 2016, 7, 12494.

[14] K. L. Zhu, M. P. Shaver, S. P. Thomas, Chem. Sci., 2016, 7, 3031-3035.

[15] N. Jana, F. Zhou, T. G. Driver, J. Am. Chem. Soc., 2015, 137, 6738-6741.

[16] T. J. Mooibroek, E. Bouwman, E. Drent, Organometallics, 2012, 31, 4142-4156.

[17] T. J. Mooibroek, L. Schoon, E. Bouwman, E. Drent, Chem. Eur. J., 2011, 17, 13318-13333.

[18] K.-S. Ju, R. E. Parales, Microbiol. Mol. Biol. Rev., 2010, 74, 250-272.

[19] A. M. Tafesh, J. Weiguny, Chem. Rev., 1996, 96, 2035-2052.

[20] R. M. Figueiredo, J. S. Suppo, J. M. Campagne, Chem. Rev., 2016, 116, 12029-12122.

[21] V. R. Pattabiraman, J. W. Bode, Nature, 2011, 480, 471-479.

[22] Q. J. Yuan, M. S. Sigman, J. Am. Chem. Soc., 2018, 140, 6527-6530.

[23] X. G. Guo, A. Facchetti, T. J. Marks, Chem. Rev., 2014, 114,
8943-9021.

[24] J. B. Peng, H. Q. Geng, F. P. Wu, D. Li, X.-F. Wu, J. Catal., 2019, 375, 519-523.

[25] J. W. Li, S. Y. Wang, S. C. Zou, H. M. Huang, Commun. Chem., 2019, 2, $1-9$.

[26] B. Gao, G. Y. Zhang, X. B. Zhou, H. M. Huang, Chem. Sci., 2018, 9, 380-386.

[27] L. Yang, L. J. Shi, Q. Xing, K. W. Huang, C. G. Xia, F. W. Li, ACS Catal., 2018, 8, 10340-10348.

[28] F. Sha, H. Alper, ACS Catal., 2017, 7, 2220-2229.

[29] J. Liu, H. Q. Li, A. Spannenberg, R. Franke, R. Jackstell, M. Beller, Angew. Chem. Int. Ed., 2016, 55, 13544-13548.

[30] T. Y. Xu, F. Sha, H. Alper, J. Am. Chem. Soc., 2016, 138, 6629-6635.

[31] X. Y. Li, X. W. Li, N. Jiao, J. Am. Chem. Soc., 2015, 137, 9246-9249.

[32] H. Q. Li, K. W. Dong, H. Neumann, M. Beller, Angew. Chem. Int. Ed., 2015, 54, 10239-10243.

[33] G. Y. Zhang, B. Gao, H. M. Huang, Angew. Chem. Int. Ed., 2015, 54, 7657-7661.

[34] K. W. Dong, X. J. Fang, R. Jackstell, G. Laurenczy, Y. H. Li, M. Beller, J. Am. Chem. Soc., 2015, 137, 6053-6058.

[35] X. J. Fang, R. Jackstell, M. Beller, Angew. Chem., Int. Ed., 2013, 52, 14089-14093.

[36] J. B. Peng, H. Q. Geng, D. Li, X. X. Qi, J. Ying, X. F. Wu, Org. Lett, 2018, 20, 4988-4993.

[37] F. Zhou, D. S. Wang, X. Y. Guan, T. G. Driver, Angew. Chem. Int. Ed., 2017, 56, 4530-4534.

[38] C. W. Cheung, M. Leendert Ploeger, X. L. Hu, Chem. Sci., 2018, 9, 655-659.

[39] H. R. Liang, L. Zhang, X. L. Zheng, H. Y. Fu, M. L. Yuan, R. X. Li, H. Chen, Chin. J. Catal., 2012, 33, 977-981.

[40] A. C. Brezny, C. R. Landis, J. Am. Chem. Soc., 2017, 139, 2778-2785.

[41] W. L. Ren, W. J. Chang, J. Dai, Y. Shi, J. F. Li, Y. A. Shi, J. Am. Chem. Soc., 2016, 138, 14864-14867.

[42] D. Semeril, C. Jeunesse, D. Matt, L. Toupet, Angew. Chem. Int. Ed., 2006, 45, 5810-5814.

[43] S. C. Bourque, F. Maltais, W. J. Xiao, O. Tardif, H. Alper, P. Arya, L. E. Manzer, J. Am. Chem. Soc., 1999, 121, 3035-3038.

[44] J. B. Peng, X. F. Wu, Angew. Chem. Int. Ed., 2018, 57, 1152-1160.

[45] D. Ding, G. H. Zhu, X. F. Jiang, Angew. Chem. Int. Ed., 2018, 57, 9028-9032.

[46] D. Ding, T. Mou, M. H. Feng, X. F. Jiang, J. Am. Chem. Soc., 2016, 138,

\section{Graphical Abstract}

Chin. J. Catal., 2020, 41: 1152-1160 doi: 10.1016/S1872-2067(20)63561-6

\section{Intermediate formation enabled regioselective access to amide in the Pd-catalyzed reductive aminocarbonylation of olefin with nitroarene}

Li Yang, Lijun Shi, Chungu Xia *, Fuwei Li *

Lanzhou Institute of Chemical Physics (LICP), Chinese Academy of Sciences

An efficient palladium-catalyzed reductive aminocarbonylation of olefins with nitroarenes was developed, providing facile access to amides with excellent regioselectivities enabled by the different $\mathrm{N}$-intermediate formation reduced from nitroarene. This route is significantly different from the previous ligand-controlled regioselective synthesis methods of amides via aminocarbonylation of

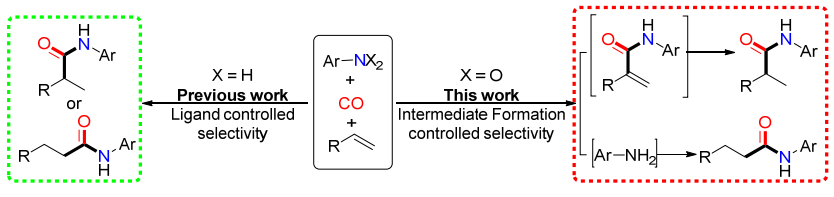
olefins with amines 
5218-5221.

[47] M. H. Feng, B. Q. Tang, N. Z. Wang, H. X. Xu, X. F. Jiang, Angew. Chem. Int. Ed., 2015, 54, 14960-14964.

[48] H. Q. Li, K. W. Dong, H. J. Jiao, H. Neumann, R. Jackstell, M. Beller, Nat. Chem., 2016, 8, 1159-1166.

[49] M. Beller, J. Seayad, A. Tillack, H. J. Jiao, Angew. Chem. Int. Ed., 2004, 43, 3368-3398.

[50] S. Matsunaka, Science, 1968, 160, 1360-1361.

[51] A. Vavasori, L. Ronchin, Pure Appl. Chem., 2012, 84, 473-484.

[52] Y. Takebayashi, K. Suea, S. Yodaa, T. Furuyaa, K. Mae, Chem. Eng. J., 2012, 180, 250-254.
[53] F. Ragaini, M. Gasperini, S. Cenini, L. Arnera, A. Caselli, P. Macchi, N. Casati, Chem. Eur. J., 2009, 15, 8064-8077.

[54] F. Paul, Coord. Chem. Rev., 2000, 203, 269-323.

[55] R. Waterman, G. L. Hillhouse, J. Am. Chem. Soc., 2003, 125, 13350-13351.

[56] S. M. Bellows, N. A. Arnet, P. M. Gurubasavaraj, W. W. Brennessel, E. Bill, T. R. Cundari, P. L. Holland, J. Am. Chem. Soc., 2016, 138, 12112-12123.

[57] M. A. Aubart, R. G. Bergman, Organometallics, 1999, 18, 811-813.

[58] C. Amatore, E. Carre, A. Jutand, M. A. M'Barki, Organometallics, 1995, 14, 1818-1826.

\title{
钯催化芳香硝基化合物与烯烃的选择性还原羰化酰胺化反应
}

\author{
杨 莉, 石利军, 夏春谷 ${ }^{*}$, 李福伟 ${ }^{*}$ \\ 中国科学院兰州化学物理研究所, 羰基合成与选择氧化国家重点实验室, 甘肃兰州730000
}

\begin{abstract}
摘要: 与芳香胺相比, 芳香硝基化合物具有廉价易得、官能团兼容性好等优点, 作为氮源在下游含氮化学品合成中具有广 泛的应用. 目前烯烃羰化酰胺化反应绝大多数以胺类化合物为氮源, 其中直链和支链酰胺产物的选择性主要是通过具有 特定电子和位阻特性的配体调控实现. 已报道的芳香硝基化合物的还原酰胺化反应研究中, 需要外加还原剂或者利用金 属羰基化合物 $\mathrm{Mo}(\mathrm{CO})_{6}$ 释放的 $\mathrm{CO}$ 为羰基源和还原剂. 本文发展了一种冊须外加还原剂的钯催化芳香硝基化合物与烯烃的 还原羰化酰胺化反应新方法.

研究发现, 钯金属催化剂(特别是离子型)的抗衡阴离子是还原羰化酰胺化反应中化学选择性和嵳炭化区域选择性的关键 因素. 抗衡阴离子为氯离子、嗍酸为助剂时, 最优钯前驱物 $\mathrm{K}_{2} \mathrm{PdCl}_{4}$ 的产物主要为支链酰胺, 此时不同的膦配体并不能调控 其区域选择性, 这与胺的烯烃酰胺化反应可以通过配体调控羰化的区域选择性表现出明显的不同. 含氮中间体原位捕捉、 硝基化合物还原下游可能中间体对照实验等研究表明, 芳香硝基化合物在以一氧化碳为还原剂的催化还原体系下被完全 脱氧还原为氮烯(Ar-N:), 再经过烯酰胺中间体进一步烯键还原得到相应的支链酰胺; 当离子型钯前驱物的抗衡阴离子配 位性较弱时, 最优钯前驱物为 $\mathrm{Pd}\left(\mathrm{CH}_{3} \mathrm{CN}\right)_{4}(\mathrm{OTf})_{2}$ 时, 以直链酰胺为主要产物, 此时不同的膦配体可以调控酰胺化的区域选 择性. 同样的机理研究表明, 在该催化剂体系下芳香硝基化合物首先被还原为芳基胺, 然后再发生与现有报道类似的胺类 化合物的烯烃羰化酰胺化反应. 这两个催化反应体系都表现出了较好的底物适用性, 并且可以高效地应用于除草剂(敌稗) 的一步合成. 本文为以硝基化合物为起始氮源, 通过催化控制生成特定含氮中间体, 从而可控合成不同的含氮化学品提供 了一条新思路.
\end{abstract}

关键词: 芳香硝基化合物; 酰胺; $N$-中间体; 氨基羰基化; 区域选择性

收稿日期: 2019-10-22. 接受日期: 2019-12-01. 出版日期: 2020-07-05.

*通讯联系人. 电子信箱: cgxia@licp.cas.cn

通讯联系人. 电子信箱: fuweili@licp.cas.cn 基金来源: 国家重点研发计划(2018YFB1501600); 国家自然科学基金(21773271, 21972151).

本文的电子版全文由Elsevier出版社在ScienceDirect上出版(http://www.sciencedirect.com/science/journal/18722067). 